\title{
Penilaian Autentik Pada Pembelajaran Tematik Kelas IV di Madrasah Ibtidaiyah Darussalam 01 Bagon Puger Jember
}

\author{
Dwi Isnaini \\ MI Darussalam 01 Jember \\ Dwiisnaini352@gmail.com \\ Lailatul Usriyah \\ IAIN Jember \\ lailatulusriyah78@gmail.com
}

\begin{abstract}
Abstrak
Penilaian autentik ini bertujuan untuk mendeskripsikan pengetahuan guru serta menggambarkan tugas-tugas riil bagi siswa untuk menghasilkan pengetahuan, sikap dan keterampilan. Teknik pengumpulan data yang digunakan adalah observasi dan wawancara. Fokus penelitian ini yaitu: (1) Bagaimana penilaian kompetensi sikap pada pembelajaran tematik di MI Darussalam 01 Bagon Puger Jember? (2) Bagaimana penilaian kompetensi pengetahuan pada pembelajaran tematik di MI Darussalam 01 Bagon Puger Jember? (3) Bagaimana penilaian kompetensi keterampilan pada pembelajaran tematik di MI Darussalam 01 Bagon Puger Jember? Hasil dari penelitian ini menunjukkan: (a) Penilaian kompetensi sikap meliputi sikap jujur dan disiplin, dimana mudah didalam teori, namun sulit untuk menerapkannya. Tergantung dari guru favorit masing-masing, proses pembelajaran tergantung pada materi pelajarannya, dan juga berkaitan dengan nilai atau norma. (b) Penilaian kompetensi pengetahuan, meliputi: tes tulis, tes lisan, dan penugasan, baik penugasan terstruktur dan tidak terstruktur. (c) Penilaian kompetensi keterampilan meliputi: penilaian kinerja, penilaian proyek, dan penilaian portofolio.
\end{abstract}

Kata Kunci: Penilaian Autentik; Pembelajaran Tematik 


\section{PENDAHULUAN}

Penilaian (assessment) dalam Kamus Besar Bahasa Indonesia (KBBI) berasal dari kata nilai, yang berarti kepandaian, biji dan ponten. ${ }^{1}$ Sedangkan penilaian yaitu suatu proses, cara, perbuatan menilai, pemberian nilai (biji, kadar mutu, harga). Penilaian dapat diartikan sebagai proses untuk mendapatkan informasi dalam bentuk apapun yang dapat digunakan untuk dasar pengambilan keputusan berkaitan dengan upaya perkembangan siswa, baik yang menyangkut kurikulum, program belajar, iklim sekolah maupun kebijakan-kebijakan sekolah.

Dalam kitab Ruhuat-tarbiyah Wa at-ta'lim karya Syeikh Muhammad Athiyah Al-Abrasy yang artinya dikatakan sebagai berikut:

Evaluasi atau penilaian adalah ujian yang dilakukan oleh sekolah untuk mengetahui kadar kemampuan siswa terhadap materi yang telah mereka pelajari dan untuk mengetahui kelemahan siswa (mendiagnosis), bisa berbentuk lisan, tulisan dan perbuatan. ${ }^{2}$

Sedangkan menurut Douglas Brown, assessment is a method used to measure the ability, knowledge or performance of a person. (penilaian adalah metode yang digunakan untuk mengukur kemampuan, pengetahuan atau performa seseorang). Douglas Brown menambahkan bahwa "Assessment is an ongoing process that encompasses a much wider domain." (Penilaian merupakan proses yang berkelanjutan yang mencakup domain/ ranah yang lebih luas).

Pengertian yang dikemukakan Brown ini, lebih jelas memberikan gambaran kepada kita, bahwa penilaian dilakukan sebagai sebuah metode pengukuran atas pengetahuan, kemampuan dan performa seseorang serta bersifat terus menerus.

Lebih lanjut lagi, menurut Ann Gravells:

\footnotetext{
1 Departemen Pendidikan Nasional, Kamus Besar Bahasa Indonesia (Jakarta: Balai Pustaka, 2002), Edisi ke-3, 783.

${ }^{2}$ Muhammad Athiyah Al-Abrasy, Ruhuttarbiyah Watta'lim, (Beirut: Darul Iliya, 1950), 362.

${ }^{3}$ Douglas Brown, Language Assessment Principles and Classroom Practices (San Fransisco: Longman, 2004), 4.
} 
Assessment is a way of finding out if learning has taken place. It enables you, the assessor, to ascertain if your learner has gained the required skills and knowledge needed at a given point towards their programme or qualification. ${ }^{4}$ (Penilaian adalah cara untuk mencari tahu apakah pembelajaran telah terjadi. Hal ini memungkinkan anda sebagai penilai, untuk memastikan apakah dalam pembelajaran telah memperoleh keterampilan dan pengetahuan yang diperlukan melalui program atau kualifikasi mereka).

Penilaian adalah suatu prosedur sistematis dan mencakup kegiatan mengumpulkan, menganalisis serta menginterpretasikan informasi yang dapat digunakan untuk membuat kesimpulan tentang karakteristik seseorang atau objek. Secara khusus untuk dunia pendidikan, Gronlund Linn (dalam Kuseri Suprananto), mendefinisikan penilaian sebagai suatu proses yang sistematis dan mencakup kegiatan mengumpulkan, menganalisis, serta menginterpretasikan informasi untuk menentukan seberapa jauh seorang siswa atau sekelompok siswa mencapai tujuan pembelajaran yang telah ditetapkan, baik aspek pengetahuan, sikap maupun keterampilan. ${ }^{5}$

Dengan demikian, penilaian adalah proses pengumpulan berbagai data yang bisa memberikan gambaran perkembangan belajar siswa. Gambaran perkembangan peserta didik perlu diketahui oleh guru agar bisa memastikan bahwa peserta didik mengalami proses pembelajaran dengan benar.

Sedangkan istilah autentik merupakan sinonim dari asli, nyata, valid atau reliable. ${ }^{6}$ Autentik berarti keadaan yang sebenarnya, yaitu kemampuan atau keterampilan yang dimiliki oleh peserta didik. Misalnya, peserta didik diberi tugas proyek untuk melihat kompetensi peserta didik dalam menerapkan pengetahuan yang dimiliki peserta didik dalam kehidupan sehari-hari atau dunia nyata.

\footnotetext{
${ }^{4}$ Ann Gravells, Principles and Practice of Assessment in the Life Long Learning Sector (Inggris: Learning Matters, 2009), 7.

${ }^{5}$ Kuseri Suprananto, Pengukuran dan Penilaian Pendidikan, (Yogyakarta: Graha Ilmu, 2012), 8 .

${ }^{6}$ Kementerian Pendidikan dan Kebudayaan. Konsep Penilaian Autentik pada Proses dan HasilBelaja(PPT),https://docs.google.com/presentation/d/1Z2KmwgPpH4xZ_BTYjndfveO TRPDii8SUmXt3NFRsvu0/edit?pli=1\#slide=id.p17.
} 
Penilaian autentik adalah kegiatan menilai peserta didik yang menekankan pada apa yang seharusnya dinilai, baik proses maupun hasil dengan berbagai instrumen penilaian. Menurut Nurgiyantoro (dalam Yunus Abidin), menyatakan bahwa pada hakikatnya penilaian autentik merupakan kegiatan penilaian yang dilakukan tidak semata-mata untuk menilai hasil belajar siswa, melainkan juga berbagai faktor yang lain, antara lain kegiatan pengajaran yang dilakukan itu sendiri. ${ }^{7}$

Dalam definisi yang lebih fokus, misalnya O’Malley dan Pierce dalam Yunus Abidin mendefinisikan penilaian autentik sebagai berikut:

Authentic assessment is an evaluation process that involves multiple froms of performance measurement reflecting the student's learning, achievement, motivation, and attitudes on instructionally relevant activities. Example of authentic assessment techniques include performance assessment, portofolio, and self-assessment. ${ }^{8}$ (Penilaian autentik adalah proses evaluasi yang melibatkan berbagai bentuk pengukuran kinerja yang mencerminkan belajar siswa, prestasi, motivasi, dan sikap dalam aktivitas pembelajaran yang saling berkaitan. Contoh teknik penilaian autentik termasuk penilaian kinerja, portofolio, dan penilaian diri).

Penilaian autentik juga merupakan istilah yang digunakan untuk menggambarkan tugas-tugas riil yang dibutuhkan siswa-siswi, untuk dilaksanakan dalam menghasilkan pengetahuan mereproduksi informasi. Sebagai contoh, dalam pembelajaran membaca, seorang siswa belumlah dikatakan belajar secara bermakna bilamana dia belum mampu menyusun prediksi, membuktikan prediksi, dan menceritakan kembali isi bacaan. Oleh karena itu guru-guru perlu adanya pelatihan-pelatihan ataupun pembekalan yang berkelanjutan ke seluruh guru-guru dasar, tentang bagaimana pelaksanaan penilaian autentik untuk menjamin pembentukan kompetensi riil pada siswa. 77.

${ }^{7}$ Yunus Abidin Abidin, Desain Sistem Pembelajaran Dalam Konteks Kurikulum 2013, ${ }^{8}$ Ibid., 80 . 
Berdasarkan konteks diatas, maka permasalahan dalam pembelajaran tematik di Madrasah Ibtidaiyah Darussalam 01, lembaga pendidikan swasta yang berada di Desa Bagon Kecamatan Puger Kabupaten Jember sebagian besar masih kurang memahami tentang penilaian autentik pada pembelajaran tematik, baik terkait perencanaan, pelaksanaan, maupun evaluasinya.

Lembaga pendidikan, memang memiliki tanggung jawab dalam memajukan lembaganya, melalui upaya membina peserta didiknya secara optimal. Namun, upaya yang dilakukan oleh lembaga untuk meningkatkan kualitas peserta didik dan meningkatkan kualitas manajemen lembaganya sudah sering dilakukan, namun masih belum maksimal. Hal tersebut disebabkan banyaknya daya saing antar lembaga yang sangat kuat mulai dari aspek manajemen, kurikulum dan lain-lainnya. Berangkat dari temuan masalah yang ditemukan di lapangan inilah, maka penulis sangat tertarik dan penulis merasa perlu adanya kajian lebih lanjut serta melakukan penelitian tentang "Penilaian Autentik pada Pembelajaran Tematik di Madrasah Ibtidaiyah Darussalam 01 Dusun Suling Desa Bagon Kecamatan Puger Kabupaten Jember”.

\section{METODE PENELITIAN}

Pendekatan yang digunakan dalam penelitian ini adalah kualitatif, dengan jenis penelitian studi kasus. Penelitian ini dilakukan di Madrasah Ibtida'iyah Darussalam 01, yang berlokasi di Dusun Suling Desa Bagon Kecamatan Puger Kabupaten Jember. Penentuan subyek penelitian menggunakan purposive. Informan yang ditetapkan dalam penelitian ini adalah Kepala Madrasah, Guru Kelas IV, dan Peserta Didik. Teknik pengumpulan data yaitu: wawancara, observasi, dan dokumentasi. Analisis data secara interaktif dengan model Miles dan Huberman, dengan langkahlangkah yaitu: kondensasi, penyajian data, dan verifikasi. Keabsahan data yang digunakan yaitu triangulasi sumber dan teknik. 


\section{HASIL DAN PEMBAHASAN TEMUAN}

Dari hasil temuan yang sudah peneliti sajikan. Berikut ini akan dibahas dengan pendekatan teori-teori yang dipaparkan oleh para tokoh dengan temuan di lapangan. Maka akan dilanjutkan mengenai temuan yang didapat dari lapangan sebagai berikut:

\section{Penilaian Kompetensi Sikap Pada Pembelajaran Tematik di Madrasah Ibtidaiyah Darussalam 01 Bagon Puger Jember}

Penilaian autentik sering digambarkan sebagai penilaian atas perkembangan peserta didik yang berfokus pada kemampuan mereka dalam perkembangan belajarnya dan menjadi subjek aktif. Idealnya, penilaian autentik harus mampu menggambarkan sikap, keterampilan dan pengetahuan tentang apa yang sudah atau belum dimiliki oleh peserta didik, bagaimana mereka menerapkan pengetahuannya, apakah mereka sudah maupun belum mampu menerapkan belajarnya dan lain sebagainya. ${ }^{9}$

Penilaian autentik merupakan kegiatan menilai peserta didik yang menekankan pada apa yang seharusnya dinilai, baik dilihat dari proses maupun hasil dengan berbagai instrumen penilaian yang disesuaikan dengan tuntutan kompetensi. ${ }^{10}$

Penilaian kompetensi sikap dalam pembelajaran, merupakan serangkaian kegiatan yang dirancang untuk mengukur sikap peserta didik sebagai hasil dari suatu program pembelajaran. Penilaian sikap yang diterapkan di Madrasah Ibtidaiyah Darussalam 01 Desa Bagon Kecamatan Puger Kabupaten Jember, meliputi beberapa aspek yaitu: sikap terhadap materi, sikap terhadap guru/ pengajar, sikap terhadap proses pembelajaran, serta sikap yang berkaitan dengan nilai atau norma yang berhubungan dengan materi pembelajaran.

\footnotetext{
${ }^{9}$ Abdul Majid, Penilaian Autentik proses dan hasil belajar., 250.

${ }^{10}$ Nino Nurjananto dan Ersanghono Kusomo, "Pengembangan Instrumen Penilaian Autentik Untuk Mengukur Kompetensi Peserta Didik Materi Senyawa Hidrokarbon", Jurnal Inovasi Pendidikan Kimia, Vol 9, No. 2, 2015, 1576.
} 


\section{Sikap Jujur dan Disiplin}

Dalam bersikap atau bertingkah laku setiap harinya, pastinya setiap orang berbeda, apa lagi peserta didiknya. Namun sikap jujur dan disiplin, merupakan sikap yang harus dan penting untuk ditanamkan kepada peserta didik.

Sikap jujur dan disiplin tidak cukup hanya dalam teori saja, namun perlu adanya praktek yang nantinya akan ditiru oleh peserta didik. Oleh karena itu, guru harus mengaca kepada sikap ideal dan fitrahnya yaitu di gugu dan ditiru, sehingga akan melatih siswa untuk bersikap sebagaimana guru mempraktekkannya.

\section{Sikap Terhadap Guru/ Pengajar}

Peserta didik perlu memiliki sikap positif terhadap guru. Peserta didik yang tidak memiliki sikap positif terhadap guru akan cenderung mengabaikan hal-hal yang diajarkan. Dengan demikian, peserta didik yang memiliki sikap negatif terhadap guru akan sukar menyerap materi pelajaran yang diajarkan oleh guru tersebut. ${ }^{11}$

Sedangkan dalam memahami materi pembelajaran, peserta didik tergantung dari sikap mereka terhadap guru, dimana ketika mereka memiliki sikap positf maka akan mudah memahami materi pembelajaran. Sedangkan jika memiliki sikap negatif maka akan sukar memahami materi pembelajaran.

\section{Sikap Terhadap Proses Pembelajaran}

Peserta didik juga perlu sikap positif terhadap proses pembelajaran yang berlangsung. Proses pembelajaran mencakup suasana pembelajaran, strategi, metodologi, dan teknik pembeiajaran yang digunakan. Proses pembelajaran yang rnenarik, nyaman dan menyenangkan dapat

\footnotetext{
${ }^{11}$ Abdul Majid, Penilaian Autentik proses., 168.
} 
menumbuhkan motivasi belajar peserta didik, sehingga dapat mencapai hasil belajar yang maksimal. ${ }^{12}$

Dalam pelaksanaan proses pembelajaran yang menarik, nyaman dan menyenangkan yang dapat menumbuhkan motivasi belajar peserta didik, tergantung keahlian seorang guru dalam merancang sebuah pembelajaran. Bukan hanya dapat memudahkan peserta didik dalam menerima materi pembelajaran, namun juga bagaimana memudahkan guru didalam mengajarnya. Di tambah dengan adanya penyampaian tentang bagaimana cara peserta didik bersikap baik (transfer of value).

\section{Sikap Berkaitan Dengan Nilai Atau Norma Yang Berhubungan Dengan Suatu Materi Pelajaran}

Peserta didik juga perlu memiliki sikap yang tepat, yang dilandasi oleh nilai-nilai positif terhadap kasus lingkungan tertentu (kegiatan pelestarian/ kasus perusakan lingkungan hidup). Misalnya, peserta didik memiliki sikap positif terhadap program perlindungan satwa liar. (Modul Pedoman Penilaian Kurikulum 2013). ${ }^{13}$

Jadi, nilai merupakan sesuatu yang baik, diinginkan, dicita-citakan dan dipentingkan oleh masyarakat. Sedangkan norma adalah kaidah atau pedoman, aturan berperilaku untuk mewujudkan keinginan dan cita-cita tersebut, atau boleh dikatakan nilai adalah pola yang diinginkan. Sedangkan norma adalah pedoman atau cara-cara untuk mencapai nilai tersebut.

Berdasarkan hasil wawancara dan observasi tentang penilaian sikap di Madrasah Ibtidaiyah Darussalam 01 Desa Bagon, bahwa ada empat poin yang menjadi tolak ukur untuk mendapatkan nilai dari penilaian sikap, yaitu dilihat dari sikap terhadap materi pelajaran, sikap terhadap guru, sikap terhadap proses pembelajaran, serta sikap yang berkaitan dengan nilai atau norma yang berhubungan dengan suatu materi pelajaran.

\footnotetext{
${ }^{12}$ Ibid., 168.

${ }^{13}$ Abdul Majid, Penilaian Autentik proses., 168.
} 
Tabel 1.1

Hasil Penilaian Sikap Siswa Kelas IV MI Darussalam 01 Suling Bagon Puger Jember

\begin{tabular}{|c|c|c|c|c|c|}
\hline \multirow[b]{2}{*}{ No } & \multirow[b]{2}{*}{ Nama } & \multicolumn{4}{|c|}{ PENILAIAN SIKAP } \\
\hline & & $\begin{array}{c}\text { Jujur } \\
\text { dan } \\
\text { Disiplin }\end{array}$ & $\begin{array}{c}\text { Terhadap } \\
\text { Guru/Pengajar }\end{array}$ & $\begin{array}{c}\text { Terhadap } \\
\text { Proses } \\
\text { Pembelajaran }\end{array}$ & $\begin{array}{c}\text { Berkaitan } \\
\text { dengan } \\
\text { Nilai/Norma }\end{array}$ \\
\hline 1 & Ali Gufron & 78 & 81 & 77 & 79 \\
\hline 2 & Arini Nabila & 77 & 80 & 76 & 80 \\
\hline 3 & Asrul Ananda & 75 & 78 & 78 & 80 \\
\hline 4 & $\begin{array}{l}\text { Difa Wahyu } \\
\text { Lestari }\end{array}$ & 76 & 78 & 79 & 78 \\
\hline 5 & $\begin{array}{l}\text { Ihyek Ulum } \\
\text { Mudin }\end{array}$ & 76 & 77 & 80 & 77 \\
\hline 6 & $\begin{array}{l}\text { Jesika Fitri } \\
\text { Rahmania }\end{array}$ & 80 & 76 & 80 & 75 \\
\hline 7 & Kurniawan & 79 & 78 & 78 & 76 \\
\hline 8 & Lailatun Nabila & 81 & 79 & 78 & 76 \\
\hline 9 & M. Hafid & 80 & 80 & 77 & 80 \\
\hline 10 & $\begin{array}{l}\text { M. Ravel Izzat } \\
\text { Hakiki }\end{array}$ & 78 & 80 & 75 & 79 \\
\hline 11 & $\begin{array}{l}\text { Medischa Roza } \\
\text { Almahira }\end{array}$ & 78 & 78 & 76 & 78 \\
\hline 12 & $\begin{array}{l}\text { Moch. Anam } \\
\text { Maulana Ishak }\end{array}$ & 77 & 77 & 76 & 77 \\
\hline 13 & $\begin{array}{l}\text { Muhammad } \\
\text { Nuri }\end{array}$ & 76 & 75 & 80 & 75 \\
\hline 14 & $\begin{array}{l}\text { Nis Rina Nova } \\
\text { Vara Dila }\end{array}$ & 78 & 76 & 79 & 76 \\
\hline 15 & Nurmalia Laili & 79 & 76 & 81 & 76 \\
\hline 16 & Siti Aisyah & 80 & 80 & 80 & 80 \\
\hline 17 & Siti Nur Aini & 80 & 79 & 80 & 79 \\
\hline
\end{tabular}

Penilaian Kompetensi Pengetahuan Pada Pembelajaran Tematik di Madrasah Ibtidaiyah Darussalam 01 Bagon Puger Jember

Aspek pengetahuan dapat dinilai dengan cara berikut ini:

\section{Tes Tulis}

Meski konsepsi penilaian autentik muncul dari ketidakpuasan terhadap tes tertulis yang lazim dilaksanakan pada era sebelumnya, akan 
tetapi penilaian tertulis atas hasil pembelajaran tetap harus dan bisa dilakukan. Tes tertulis terdiri dari, pertama, memilih atau mensuplai jawaban dan uraian. Kedua, memilih jawaban terdiri dari pilihan ganda, pilihan benar-salah, ya/ tidak, menjodohkan dan sebab-akibat. Ketiga, mensuplai jawaban terdiri dari isian atau melengkapi, jawaban singkat atau pendek dan uraian.

Tes tertulis berbentuk uraian atau esai menuntut peserta didik mampu mengingat, memahami, mengorganisasikan, menerapkan, menganalisis, mensintesis, mengevaluasi dan sebagainya atas materi yang sudah dipelajari. Tes tertulis berbentuk uraian, sebisa mungkin bersifat komprehensif, sehingga mampu menggambarkan ranah sikap, keterampilan dan pengetahuan peserta didik. Pada tes tertulis berbentuk esai, peserta didik berkesempatan memberikan jawabannya sendiri yang berbeda dengan teman-temannya, namun tetap terbuka memperoleh nilai yang sama.

\section{Tes Lisan}

Tes lisan berupa pertanyaan-pertanyaan yang diberikan guru secara ucap (oral), sehingga peserta didik merespons pertanyaan tersebut secara ucap juga dan menimbulkan keberanian. Jawaban dapat berupa kata, frase, kalimat maupun paragraf yang diucapkan.

\section{Penugasan}

Penugasan adalah penilaian yang dilakukan oleh pendidik yang dapat berupa pekerjaan rumah, baik secara individu maupun kelompok, sesuai dengan karakteristik tugasnya. ${ }^{14}$ Penugasan disini ada dua yaitu: tugas terstruktur, dimana tugas yang diberikan kepada siswa dalam rangka meningkatkan pemahamannya terhadap suatu materi pembelajaran, dimana waktu pengumpulan ditentukan oleh guru biasanya ditentukan pada pertemuan berikutnya. Sedangkan tugas tidak terstruktur yaitu tugas yang

${ }^{14}$ Ibid., 254. 
diberikan kepada siswa dalam jangka waktu yang cukup lama, misalnya satu bulan atau bahkan satu semester.

Sedangkan hasil dari penyajian dan analisis data, bahwasannya penilaian kompetensi pengetahuan ini digunakan untuk menilai ketercapaian peserta didik dalam mencapai tujuan yang hendak dicapai, dalam hal pemahaman konsep peserta didik tentang materi pelajaran yang sudah diterima.Seperti halnya penilaian kompetensi sikap, sebelum melaksanakan penilaian kompetensi pengetahuan, perlu disiapkan perencanaan penilaian yang meliputi silabus, RPP, dan buku nilai.Dalam perencanaan penilaian kompetensi pengetahuan yang terdapat pada RPP.

Pada sisi penilaian pengetahuan tersebut, berdasarkan paparan data hasil penelitian tentang proses pelaksanaan penilaian pengetahuan ini yang didapat dari hasil observasi, wawancara, dan dokumentasi. Jenis penilaian yang digunakan dalam menilai kompetensi pengetahuan meliputi tes tertulis, tes lisan, dan penugasan. Hal tersebut sesuai dengan apa yang disampaikan oleh Fitriyah selaku Guru Kelas IV di Madrasah Ibtidaiyah Darussalam 01 Desa Bagon.

Berdasarkan temuan data dan relevansi dengan teori diatas, dapat disimpulkan bahwa pada penilaian kompetensi pengetahuan benar-benar menggunakan tiga jenis penilaian, yaitu tes tertulis, tes lisan, dan penugasan.Dalam pelaksanaannya disesuaikan dengan perencanaan yang telah dibuat sebelumnya. Selain itu, biasanya di tambahkan latihan-latihan guna memperdalam materi yang terdapat dalam buku siswa.

Tabel 1.2

Hasil Penilaian Kompetensi Pengetahuan Siswa Kelas IV MI Darussalam 01Bagon Puger Jember

\begin{tabular}{|c|c|c|c|c|}
\hline \multirow{2}{*}{ No } & \multirow{2}{*}{ Nama } & \multicolumn{3}{|c|}{ Penilaian Kompetensi Pengetahuan } \\
\cline { 3 - 5 } & & Tes Tulis & Tes Lisan & Penugasan \\
\hline
\end{tabular}




\begin{tabular}{|c|l|c|c|c|}
\hline 1 & Ali Gufron & 81 & 79 & 78 \\
\hline 2 & Arini Nabila & 80 & 80 & 77 \\
\hline 3 & Asrul Ananda & 78 & 80 & 75 \\
\hline 4 & Difa Wahyu Lestari & 78 & 78 & 76 \\
\hline 5 & Ihyek Ulum Mudin & 77 & 77 & 76 \\
\hline 6 & Jesika Fitri Rahmania & 76 & 75 & 80 \\
\hline 7 & Kurniawan & 78 & 76 & 79 \\
\hline 8 & Lailatun Nabila & 79 & 76 & 81 \\
\hline 9 & M. Hafid & 80 & 80 & 80 \\
\hline 10 & M. Ravel Izzat Hakiki & 80 & 79 & 80 \\
\hline 11 & Medischa Roza Almahira & 78 & 80 & 75 \\
\hline 12 & Moch. Anam Maulana & 78 & 78 & 76 \\
\hline 13 & Ishak & 77 & 77 & 76 \\
\hline 14 & Nuhammad Nuri & 76 & 75 & 80 \\
\hline 15 & Nurmalia Laili & 78 & 76 & 79 \\
\hline 16 & Siti Aisyah & 79 & 76 & 81 \\
\hline 17 & Siti Nur Aini & 78 & 76 & 79 \\
\hline
\end{tabular}

Penilaian Kompetensi Keterampilan Pada Pembelajaran Tematik di Madrasah Ibtidaiyah Darussalam 01 Bagon PugerJember

Aspek keterampilan dapat dinilai dengan cara berikut:

\section{Penilaian Kinerja}

Penilaian kinerja adalah suatu penilaian yang meminta siswa untuk melakukan suatu tugas pada situasi yang sesungguhnya, yang dapat mengaplikasikan pengetahuan dan keterampilan yang disesuaikan dengan apa yang dibutuhkan. Misalnya tugas memainkan alat musik, menggunakan mikroskop, menyanyi bermain peran, menari.

Penilaian autentik sebisa mungkin melibatkan partisipasi peserta didik, khususnya dalam proses dan aspek-aspck yang akan dinilai. Guru dapat melakukannya dengan meminta para peserta didik menyebutkan 
unsur-unsur proyek/tugas yang akan mereka gunakan untuk menentukan kriteria penyelesaiannya. Dengan menggunakan informasi ini, guru dapat memberikan umpan balik terhadap kinerja peserta didik baik dalam bentuk laporan naratif maupun laporan kelas.

Penilaian kinerja memerlukan pertimbangan-pertimbangan khusus. Pertama, langkah-langkah kinerja harus dilakukan peserta didik untuk menunjukkan kinerja yang nyata, untuk suatu atau beberapa jenis kompetensi tertentu. Kedua, ketepatan dan kelengkapan aspek kinerja yang dinilai. Ketiga, kemampuan-kemampuan khusus yang diperlukan oleh peserta didik untuk menyelesaikan tugas-tugas pembelajaran. Keempat, fokus utama dari kinerja yang akan dinilai, khususnya indikator esensial yang akan diamati. Kelima, urutan dari kemampuan atau keterampilan peserta didik yang akan diamati. ${ }^{15}$

Pengamatan atas kinerja peserta didik perlu dilakukan dalam berbagai konteks untuk menetapkan tingkat pencapaian kemampuan tertentu. Untuk menilai keterampilan berbahasa peserta didik, dari aspek keterampilan berbicara misalnya, guru dapat mengobservasinya pada konteks seperti berpidato, berdiskusi, bercerita dan wawancara. Dari sini akan diperoleh keutuhan mengenai keterampilan berbicara dimaksud. Untuk mengamati kinerja peserta didik dapat menggunakan alat atau instrumen, seperti penilaian sikap, observasi, perilaku, pertanyaan langsung, atau pertanyaan pribadi.

\section{Penilaian Proyek}

Tugas-tugas belajar (learning tasks) yang meliputi kegiatan perancangan, pelaksanaan, dan pelaporan, secara tertulis maupun lisan dalam waktu tertentu ${ }^{16}$

\footnotetext{
${ }^{15}$ Rusman, Pembelajaran Tematik Terpadu.,256.

${ }^{16}$ Ruslan dkk, "Kendala Guru Dalam Menerapkan Penilaian Autentik Di SD Kabupaten Pidie”, Jurnal Ilmiah Mahasiswa Pendidikan Guru Sekolah Dasar FKIP Unsyiah (Volume 1 Nomor 1, Agustus 2016), 153.
} 


\section{Penilaian Portofolio}

Portofolio merupakan catatan atau kumpulan hasil karya siswa yang didokumentasikan secara baik dan teratur. Portofolio dapat berbentuk tugastugas yang dikerjakan siswa, jawaban siswa atas pertanyaan guru, catatan hasil obsevasi guru, catatan hasil wawancara guru dengan siswa, laporan kegiatan siswa dan karangan yang dibuat siswa. Portofolio itu beragam jenisnya, guru dapat mengumpulkannya melalui banyak cara sesuai dengan tujuan, cara yang akan dipakai, tingkatan siswa atau jenis kegiatan yang dilakukan. $^{17}$

Dalam pelaksanaan penilaian kompetensi keterampilan, terdapat tiga jenis penilaian yang digunakan, yaitu penilaian kinerja, penilaian proyek, dan penilaian portofolio. Dimana yang pertama yaitu: Tes kinerja yang dilaksanakan dengan menilai pada kegiatan siswa yang bersifat praktek. Contoh: mengukur luas meja, bercerita, dan sebagainya. Penilaian dilakukan saat siswa melakukan kinerja dan dituliskan pada buku nilai guru.

Berdasarkan relevansi antara teori dan hasil analisis data tersebut, dapat diketahui bahwa untuk penilaian kompetensi sikap dan keterampilan diambil dari nilai harian siswa, sedangkan penilaian kompetensi pengetahuan diambil dari hasil ulangan harian dan dipadukan dengan nilai keseharian.

Tabel 1.3

\section{Hasil Penilaian Kompetensi Keterampilan Siswa kelas IV MI Darussalam 01 Bagon Puger Jember}

\begin{tabular}{|c|l|c|c|c|}
\hline \multirow{2}{*}{ No } & \multirow{2}{*}{ Nama } & \multicolumn{3}{|c|}{ Penilaian Kompetensi Keterampilan } \\
\cline { 3 - 5 } & $\begin{array}{c}\text { Penilaian } \\
\text { kinerja }\end{array}$ & $\begin{array}{c}\text { Penilaian } \\
\text { Proyek }\end{array}$ & $\begin{array}{c}\text { Penilaian } \\
\text { portofolio }\end{array}$ \\
\hline 1 & Ali Gufron & 76 & 75 & 80 \\
\hline 2 & Arini Nabila & 78 & 76 & 79 \\
\hline
\end{tabular}

\footnotetext{
${ }^{17}$ Budi Santoso, "Penilaian Portofolio Dalam Matematika" Jurnal Pendidikan Matematika, (Volume 1, No.2, Juli 2007), 37.
} 


\begin{tabular}{|c|l|c|c|c|}
3 & Asrul Ananda & 79 & 76 & 81 \\
\hline 4 & Difa Wahyu Lestari & 80 & 80 & 80 \\
\hline 5 & Ihyek Ulum Mudin & 80 & 79 & 80 \\
\hline 6 & Jesika Fitri Rahmania & 78 & 80 & 75 \\
\hline 7 & Kurniawan & 78 & 78 & 76 \\
\hline 8 & Lailatun Nabila & 77 & 77 & 76 \\
\hline 9 & M. Hafid & 76 & 75 & 80 \\
\hline 10 & M. Ravel Izzat Hakiki & 80 & 79 & 80 \\
\hline 11 & $\begin{array}{l}\text { Medischa Roza } \\
\text { Almahira }\end{array}$ & 78 & 80 & 75 \\
\hline 12 & $\begin{array}{l}\text { Moch. Anam Maulana } \\
\text { Ishak }\end{array}$ & 78 & 78 & 76 \\
\hline 13 & Muhammad Nuri & 77 & 77 & 76 \\
\hline 14 & $\begin{array}{l}\text { Nis Rina Nova Vara } \\
\text { Dila }\end{array}$ & 76 & 75 & 80 \\
\hline 15 & Nurmalia Laili & 78 & 76 & 79 \\
\hline 16 & Siti Aisyah & 79 & 76 & 81 \\
\hline 17 & Siti Nur Aini & 77 & 77 & 76 \\
\hline
\end{tabular}

\section{SIMPULAN}

Berdasarkan hasil penelitian dan pembahasan, maka dapat disimpulkan bahwa Penilaian kompetensi sikap pada pembelajaran tematik di Madrasah Ibtidaiyah Darussalam 01 Desa Bagon, bahwa ada empat poin yang menjadi tolak ukur untuk mendapatkan nilai dari penilaian sikap yaitu pertama, dari sikap jujur dan disiplin, sikap ini mudah untuk diajarkan, namun sulit dalam penerapannya, sehingga membutuhkan pembiasaan sikap terhadap guru/ pengajar, dimana setiap siswa memiliki guru favorit masingmasing, sehingga berpengaruh dalam pelaksanaan kegiatan pembelajaran. Kedua, sikap terhadap proses pembelajaran hampir sama dengan guru, jadi materi yang mereka sukai akan mudah masuk. Jika tidak masuk bisa dengan cara yang lain, namun tidak dengan cara spontan melainkan secara berkelanjutan. Ketiga, sikap yang berkaitan dengan nilai atau norma. Keempat, berhubungan erat dengan materi pelajaran yang disiapkan dan diajarkan. 
Penilaian kompetensi pengetahuan pada pembelajaran tematik di Madrasah Ibtidaiyah Darussalam 01 Desa Bagon, menggunakan tiga jenis penilaian, yaitu tes tertulis, tes lisan, dan penugasan. Dalam pelaksanaannya, disesuaikan dengan perencanaan yang telah dibuat sebelumnya. Penilaian kompetensi keterampilan pembelajaran tematik di Madrasah Ibtidaiyah Darussalam 01 Desa Bagon, bahwa dalam pelaksanaannya terdapat tiga jenis penilaian yang digunakan, yaitu penilaian kinerja, penilaian proyek, dan penilaian portofolio. Penilaian kinerja yang dilaksanakan dengan menilai pada kegiatan siswa yang bersifat praktek. Contoh: mengukur luas meja, bercerita, dan sebagainya. Penilaian dilakukan saat siswa melakukan kinerja dan dituliskan pada buku nilai guru. 


\section{DAFTAR PUSTAKA}

Abidin,Yunus. Desain Sistem Pembelajaran Dalam Konteks Kurikulum 2013.

Abrasy (Al), Muhammad Athiyah. Ruhuttarbiyah Watta'lim. Beirut: Darul Iliya, 1950.

Ann Gravells. Principles and Practice of Assessment in The Life Long Learning Sector. Inggris: Learning Matters, 2009.

Brown, Douglas. Language Assessment Principles and Classroom Practices. San Fransisco: Longman, 2004.

Departemen Pendidikan Nasional. Kamus Besar Bahasa Indonesia. Edisi ke-3, Jakarta: Balai Pustaka, 2002.

Kementerian Pendidikan dan Kebudayaan. Konsep Penilaian Autentik pada Proses dan HasilBelajar(PPT),dalamhttps://docs.google.com/presentation/d/1 Z2KmwgPpH4xZ_BTYjndfveOTRPDii8SUmXt3NFRsvu0/edit?pl $\mathrm{i}=1 \#$ slide=id.p17/.

Majid, Abdul. Penilaian Autentik Proses dan Hasil Belajar. Bandung: Remaja Rosdakarya, 2014.

Majid, Abdul. Pembelaran Tematik Terpadu. Bandung: PT. Remaja Rosdakarya, 2014.

Nino Nurjananto dan Ersanghono Kusomo, "Pengembangan Instrumen Penilaian Autentik Untuk Mengukur Kompetensi Peserta Didik Materi Senyawa Hidrokarbon”. Jurnal Inovasi Pendidikan Kimia, Vol 9, No. 2, 2015.

Ruslan, dkk. "Kendala Guru Dalam Menerapkan Penilaian Autentik di SD Kabupaten Pidie”. Jurnal Ilmiah Mahasiswa Pendidikan Guru Sekolah Dasar FKIP Unsyiah Volume 1 Nomor 1, Agustus 2016. 
Dwi Isnaini, Lailatul Usriyah

Penilaian Autentik Pada Pembelajaran Tematik

Rusman. Pembelajaran Tematik Terpadu. Jakarta: Rajawali Press, 2015.

Santoso, Budi. "Penilaian Portofolio Dalam Matematika", Jurnal Pendidikan Matematika, Volume 1, No.2, Juli 2007.

Suprananto, Kuseri. Pengukuran dan Penilaian Pendidikan, Yogyakarta: Graha Ilmu, 2012. 